Article

\title{
Inhibition Activity of Plantaricin Q7 Produced by Lactobacillus plantarum Q7 against Listeria monocytogenes and Its Biofilm
}

\author{
Yinxue Liu ${ }^{1}$, Yushan Bu ${ }^{1}$, Jianxun Li $^{1}$, Yisuo Liu ${ }^{1}$, Ao Liu ${ }^{1}$, Pimin Gong ${ }^{1}$, Tongjie Liu ${ }^{1}$, Lanwei Zhang ${ }^{1}{ }^{(\mathbb{D}}$, \\ Shumei Wang ${ }^{2, *}$ and Huaxi Yi ${ }^{1, *(D)}$ \\ 1 College of Food Science and Engineering, Ocean University of China, Qingdao 266003, China; \\ liuyinxue_1121@126.com (Y.L.); bys19941003@163.com (Y.B.); lijianxun@stu.ouc.edu.cn (J.L.); \\ liuyisuo@stu.ouc.edu.cn (Y.L.); aaron_liu3124@126.com (A.L.); gongpimin@ouc.edu.cn (P.G.); \\ liutongjie@ouc.edu.cn (T.L.); zhanglanwei@ouc.edu.cn (L.Z.) \\ 2 College of Food Engineering, Harbin University, Harbin 150086, China \\ * Correspondence: wangshumei24@126.com (S.W.); yihx@ouc.edu.cn (H.Y.); Tel.: +86-0451-15304650558 (S.W.); \\ +86-0532-8203-2162 (H.Y.)
}

Citation: Liu, Y.; Bu, Y.; Li, J.; Liu, Y.; Liu, A.; Gong, P.; Liu, T.; Zhang, L.; Wang, S.; Yi, H. Inhibition Activity of Plantaricin Q7 Produced by

Lactobacillus plantarum Q7 against

Listeria monocytogenes and Its Biofilm. Fermentation 2022, 8, 75. https:// doi.org/10.3390/fermentation8020075

Academic Editor: Angela Capece

Received: 22 January 2022

Accepted: 8 February 2022

Published: 10 February 2022

Publisher's Note: MDPI stays neutral with regard to jurisdictional claims in published maps and institutional affiliations.

Copyright: (C) 2022 by the authors. Licensee MDPI, Basel, Switzerland. This article is an open access article distributed under the terms and conditions of the Creative Commons Attribution (CC BY) license (https:// creativecommons.org/licenses/by/ $4.0 /)$.

\begin{abstract}
Plantaricin Q7 is a broad-spectrum antimicrobial peptide produced by Lactobacillus plantarum Q7. The effects of plantaricin Q7 on Listeria monocytogenes and its biofilm were investigated. The results showed that plantaricin Q7 changed the cell membrane permeability and integrity of Listeria monocytogenes significantly. The extracellular lactate dehydrogenase activity increased from 156.74 U/L to $497.62 \mathrm{U} / \mathrm{L}$, and the $\mathrm{K}^{+}$concentration was increased rapidly from $0.02 \mathrm{~g} / \mathrm{L}$ to $0.09 \mathrm{~g} / \mathrm{L}$. Furthermore, the flagellum motility of Listeria monocytogenes reduced and the relative adhesion rate decreased about 30\% after treatment with plantaricin Q7. Meanwhile, the morphology and structure of Listeria monocytogenes cell and biofilm were damaged. These findings suggested that plantaricin Q7 exhibited significant inhibitory effects on not only Listeria monocytogenes cell but also its biofilm, which might be used as a natural and effective biological preservative for food storage.
\end{abstract}

Keywords: plantaricin Q7; food preservatives; Listeria monocytogenes; antibacterial activity; biofilm

\section{Introduction}

The attention of food safety has raised since the improvement of people's living standards and the enhancement of health awareness. Among all kinds of food safety incidents, food poisoning caused by microbial contamination accounts for the highest proportion. The World Health Organization (WHO) estimated that 70\% of food-borne illness were caused by food and drinking water contaminated with disease-causing microorganisms [1]. In the microbial risk management system, the monitoring of biological hazards in food and the detection of common pathogenic bacteria had been listed as important aspects [2,3].

Listeria monocytogenes, as a serious pathogenic bacteria, widely exists in water, soil and food, which could cause pregnancy abortion, sepsis, meningitis and encephalitis, as well as some diarrhea, skin infection [4]. Although the incidence of $L$. monocytogenes contamination is not high, its mortality rate $(20 \sim 30 \%)$ is much higher than that of other common foodborne pathogens [5]. L. monocytogenes has become a hot spot for food safety prevention and control due to its ability to survive in many harsh environments, such as low temperature, high pressure and low $\mathrm{pH}[6-8]$. In addition, it was confirmed that L. monocytogenes could adhere to polystyrene, glass and stainless steel surfaces and form biofilms, which was closely relevant to its pathogenicity and drug resistance [9]. Current physical and chemical sterilization methods had some potential serious problems such as chemical residue and drug resistance [10-12]. There are urgent demands for the discovery of new antimicrobial strategy against $L$. monocytogenes. 
Bacteriocins of lactic acid bacteria (LAB) are a kind of proteinaceous metabolites with antibacterial effect, which are characterized by nontoxicity, no pollution, no side effects and no drug resistance $[13,14]$. It was proposed that bacteriocins might be a potential alternative for physical and chemical preservatives, as well as antibiotics $[15,16]$. In our previous study, plantaricin Q7 produced by L. plantarum Q7 has been proved to belong to class II bacteriocin, which showed broad-spectrum antibacterial activity against L. monocytogenes, Salmonella, Staphylococcus aureus, Shigella, Escherichia coli, Pseudomonas fluorescens, Pseudomonas putida and Pseudomonas aeruginosa [17,18]. Plantaricin Q7 showed the strongest inhibitory effect on L. monocytogenes, but its antibacterial mechanism was not revealed. In this study, the inhibition activity and mechanism of plantaricin Q7 against L. monocytogenes and its biofilm was investigated, which provided the basis for the application of plantaricin Q7 as food preservatives.

\section{Materials and Methods}

\subsection{Strain Culture and Determination of Titer}

L. plantarum Q7 was isolated from yak milk Qinghai, China and cultured into de Man, Rogosa and Sharpe (MRS) broth (Qingdao Hopebio Technology, Qingdao, China) and stored in the Functional Dairy and Probiotic Engineering Laboratory (Ocean University of China, Qingdao, China). L. monocytogenes ATCC 19115 was obtained from the Food Safety Laboratory (Ocean University of China, Qingdao, China) and cultured into brain heart infusion (BHI) broth (Qingdao Hopebio Technology, China) as the indicator strain. The strains were inoculated in broth at the concentration of $2 \%(v / v)$ and activated twice at $37{ }^{\circ} \mathrm{C}$ for $24 \mathrm{~h}$. The fermentation broth of L. plantarum Q7 was centrifuged at $4000 \mathrm{rpm}$ for 10 min. The supernatant was adjusted to $\mathrm{pH} 6.0$ with $1 \mathrm{M} \mathrm{NaOH}$ and filtered through $0.22 \mu \mathrm{m}$ filters. Then, a $3 \mathrm{KDa}$ ultrafiltration tube was used for ultrafiltration at $4000 \mathrm{rpm}$ for 30 min at $4{ }^{\circ} \mathrm{C}$. The Oxford cup method was carried out to evaluate the antibacterial activity of plantaricin Q7 against L. monocytogenes. The titer of plantaricin Q7 was determined by two-fold dilution method and calculated according to the following formula, which can represent the dosage of plantaricin Q7 with minimum inhibition of L. monocytogenes [18-20]. Afterwards, all further studies were based on the result of titer. The titer $(\mathrm{AU} / \mathrm{mL})$ was calculated by the following formula: $\mathrm{AU} / \mathrm{mL}=n \times 1000 / \mathrm{x}$. $n$ : the maximum dilution multiple. $x$ : the volume of the supernatant added.

\subsection{Growth Assay of L. monocytogenes}

The plantaricin Q7 concentrated through the ultrafiltration tube was added at the start of logarithmic growth period of L. monocytogenes, so that the final concentration of plantaricin Q7 was $400 \mathrm{AU} / \mathrm{mL}$, and $\mathrm{BHI}$ without plantaricin Q7 was used as a control. Then, the samples were incubated at $37^{\circ} \mathrm{C}$. The bacterial growth was monitored by Microplate Reader (Thermo Scientific Multiskan FC, Waltham, MA, USA) at $600 \mathrm{~nm}$ every $2 \mathrm{~h}$.

\subsection{AO/EB Fluorescence Staining}

Acridine orange (AO) (Solarbio, Beijing, China)/ethyl bromide (EB) (Thermo Fisher Scientifc, MA, USA) fluorescent staining assay was performed to detect the survival of bacteria under the condition of plantaricin Q7. Briefly, the cultured L. monocytogenes was centrifuged at $4000 \mathrm{rpm}$ for $10 \mathrm{~min}$ at $4{ }^{\circ} \mathrm{C}$. After three washes with phosphate-buffered saline (PBS, pH 7.4), the bacteria cells were collected and resuspend. Plantaricin Q7 was added into the suspension as the treatment group, so that the final concentration of plantaricin Q7 was $400 \mathrm{AU} / \mathrm{mL}$, and PBS was added as control which were incubated at $37^{\circ} \mathrm{C}$ for $4 \mathrm{~h}$. Finally, the cells were stained with AO/EB fluorescent dye for 20 min in dark. The stained cells were washed and resuspended with PBS, followed by analysis with $100 \times$ automatic fluorescence microscope (NIKON/Ni-E, Tokyo, Japan). The bacterial survival rate was calculated by ImageJ v.1.53c software [21,22]. 


\subsection{Transmission Electron Microscopy (TEM) Analyses}

Plantaricin Q7 was added to L. monocytogenes culture at the start of logarithmic growth period, so that the final concentration of plantaricin Q7 was $400 \mathrm{AU} / \mathrm{mL}$. After incubation at $37^{\circ} \mathrm{C}$ for $24 \mathrm{~h}$, the harvested cells were washed and resuspended in $2.5 \%$ glutaraldehyde (Hushi, Shanghai, China) and then fixed overnight at $4{ }^{\circ} \mathrm{C}$. Subsequently, the samples were dehydrated using alcohol and embedded in white resin, and sliced and stained. The final specimens were prepared on copper grids and observed using TEM (JEOL JEM-1200EX, Tokyo, Japan). At the same time, PBS was used to replace plantaricin Q7 as control [23].

\subsection{Determination of Intracellular Biomacromolecules}

Sodium dodecyl sulfate-polyacrylamide gel electrophoresis (SDS-PAGE) was used to analyze the leakage of intracellular biomacromolecules according to the method reported by Kang et al. with minor modifications. L. monocytogenes cells were treated with or without $400 \mathrm{AU} / \mathrm{mL}$ plantaricin $\mathrm{Q} 7$ for $10 \mathrm{~h}$ at $37^{\circ} \mathrm{C}$. The harvested cells were washed three times and then resuspended in $1 \mathrm{~mL}$ of PBS to obtain an $\mathrm{OD}_{600 \mathrm{~nm}}=1.0$. Next, ultrasonic treatment was carried out in an ice environment for $15 \mathrm{~min}$. The obtained L. monocytogenes whole-cell protein contents were added with the protein loading dye, and the mixtures were boiled for $5 \mathrm{~min}$ and cooled on ice [23]. Electrophoresis was carried out using $12 \%$ separating gel and 5\% stacking gel based on an SDS-PAGE gel preparation kit (Solarbio, Beijing, China). Finally, the coomassie brilliant blue R-250 (Sigma-Aldrich, Sigma-Aldrich, MO, USA) was used for staining [24]. For the determination of lactate dehydrogenase activity (LDH), the assay procedure was based on the method in the instructions of Nanjing Jiancheng lactate dehydrogenase kit.

\subsection{Cell Membrane Permeability Assay}

The leakage of $\mathrm{K}^{+}$and electrical conductivity were examined as the expression of the change in cell permeability. L. monocytogenes cells was resuspend in $0.1 \mathrm{~mol} / \mathrm{L}$ hydroxyethyl piperazine ethanesulfonic acid (HEPES, Thermo Fisher Scientifc, Waltham MA, USA) containing $10 \mathrm{mM}$ glucose (Hushi, Shanghai, China). The suspension $\left(10^{6} \mathrm{CFU} / \mathrm{mL}\right)$ were incubated with plantaricin $\mathrm{Q} 7$ at $37^{\circ} \mathrm{C}$, so that the final concentration of plantaricin Q7 was $400 \mathrm{AU} / \mathrm{mL}$, and then centrifuged every $30 \mathrm{~min}$. The released $\mathrm{K}^{+}$from the $L$. monocytogenes was measured by atomic absorption spectrophotometer (Daojin, Japan). The electrical conductivity was measured by conductivity meter (Shanghai Leici, China), and the plantaricin Q7-free samples was used as control [25].

\subsection{Determination of the Motility of L. monocytogenes}

For flagellum puncture test, after was cultured overnight in the BHI broth at $37^{\circ} \mathrm{C}$, the inoculation needle dipped in a small amount of L. monocytogenes culture was punctured into $0.4 \%$ soft $\mathrm{BHI}$ agar tube and incubated at $37^{\circ} \mathrm{C}$ for $48 \mathrm{~h}$, and the $0.4 \%$ soft $\mathrm{BHI}$ agar tube containing $400 \mathrm{AU} / \mathrm{mL}$ plantaricin $\mathrm{Q} 7$ was used as treatment. For the determination of motility, L. monocytogenes was inoculated into BHI broth which contained $400 \mathrm{AU} / \mathrm{mL}$ plantaricin Q7 as the treatment group and then incubated overnight at $37^{\circ} \mathrm{C}, 5 \mu \mathrm{L}$ of the culture was inoculated on the center of $0.4 \%$ soft BHI agar plate and incubated at $37^{\circ} \mathrm{C}$ for $24 \mathrm{~h}$. The spots formed by the migration of the bacteria on the plate were photographed $[24,26,27]$.

\subsection{Fibrinogen-Binding Assay}

Plantaricin Q7 was added to L. monocytogenes in the logarithmic growth period, so that the final concentration of plantaricin Q7 was $400 \mathrm{AU} / \mathrm{mL}$, and PBS was added as control. The cells were collected and then resuspended in PBS to obtain an $\mathrm{OD}_{600 \mathrm{~nm}}=1.0$. The resuspended cells were placed to polystyrene 96-well plates (Corning, New York, NY, USA) which were coated with fibrinogen and incubated at $37^{\circ} \mathrm{C}$ for $24 \mathrm{~h}$. After incubation, the supernatant was removed by washing with PBS. 95\% methanol was added and fixed for $30 \mathrm{~min}$. Then, the dried wells were stained with 1\% crystal violet (Solarbio, Beijing, 
China) for 5 min and excess dye was removed with PBS. After drying, it was redissolved with $33 \%$ glacial acetic acid. It was measured at $570 \mathrm{~nm}$ and the percentage of adhesion was determined by the formula: adhesion $\%=$ OD sample/OD control $\times 100 \%$. Each experiment was repeated three times [28].

\subsection{Effect of Plantaricin Q7 on L. monocytogenes Biofilm}

L. monocytogenes biofilm was established in accordance with previous methods [29]. Firstly, L. monocytogenes biofilm in different periods were cultured in 12-well plates (Corning, New York, NY, USA) for $12 \mathrm{~h}, 24 \mathrm{~h}$ and $48 \mathrm{~h}$ respectively to determine the best time for the formation of biofilm. For the inhibition of L. monocytogenes biofilm formation by plantaricin Q7, L. monocytogenes suspension $\left(10^{7} \mathrm{CFU} / \mathrm{mL}\right)$ and plantaricin Q7 (final concentration was $400 \mathrm{AU} / \mathrm{mL}$ ) were added to 12-well plates covered with a glass coverslip (18 $\mathrm{mm}$ $\times 18 \mathrm{~mm}$ ), and incubated at $37^{\circ} \mathrm{C}$ for $24 \mathrm{~h}$. The group without plantaricin Q7 was used as control. For the effect of plantaricin Q7 on the reduction of L. monocytogenes biofilm, the glass coverslips which has formed biofilm were gently removed to new 12-well plates containing $400 \mathrm{AU} / \mathrm{mL}$ plantaricin Q7, while equivalent amount of PBS was added as control and intervention for $24 \mathrm{~h}$.

On the one hand, the prepared samples were stained with $1 \%$ crystal violet and observed under optical microscope (Olympus CX33, China). On the other hand, the prepared samples were fixed with $2.5 \%$ glutaraldehyde at $4{ }^{\circ} \mathrm{C}$ overnight and dehydrated with graded ethanol, then the dried biofilm was coated with gold and observed by scanning electron microscopy (SEM) (VEGA3 TESCAN, Brno, Czech) [30].

\subsection{Statistical Analyses}

All analyses were performed in triplicate. One-way analysis of variance (ANOVA) was performed using IBM SPSS Statistics 22.0, and $p<0.05$ was considered statistically significant.

\section{Results and Discussion}

\subsection{Antibacterial Activity of Plantaricin Q7 against L. monocytogenes}

The diameter of inhibition zone measured by Oxford cup method was about 25.70 $\mathrm{mm}$, and the titer of plantaricin Q7 against L. monocytogenes strains calculated by two-fold dilution method was $400 \mathrm{AU} / \mathrm{mL}$, which suggested that the diameter of inhibition zone was larger than that of other bacteriocins under the same concentration conditions [22,31]. The effect of $400 \mathrm{AU} / \mathrm{mL}$ plantaricin Q7 on the growth of L. monocytogenes was shown in Figure 1A. During the logarithmic growth period, L. monocytogenes grew rapidly without the addition of plantaricin Q7, while the growth trend was inhibited after treated with plantaricin Q7. There was a slow increase of OD at the later stationary phase in the treatment group. When the L. monocytogenes cells treated by plantaricin Q7 after $12 \mathrm{~h}$ were re-inoculated into fresh growth medium, no growth of L. monocytogenes was observed. It suggested that no plantaricin Q7-resistant L. monocytogenes cell was produced and the OD value increased slightly after $12 \mathrm{~h}$ could be caused by the existence of dead L. monocytogenes cells or other substances in the culture medium. From the overall trend of L. monocytogenes growth, plantaricin Q7 had an obvious inhibitory effect on L. monocytogenes.

The killing effect of plantaricin Q7 on L. monocytogenes was shown in Figure 1B. AO can penetrate cells with intact cell membrane and embed nuclear DNA to make it emit bright green fluorescence. EB can only penetrate the cells with damaged cell membrane, and emit red fluorescence. Compared with untreated controls which were stained green, most of L. monocytogenes cells appeared to be red after treatment with $400 \mathrm{AU} / \mathrm{mL}$ plantaricin Q7, which showed that most of the cell membranes were damaged after plantaricin Q7 treatment. After calculated by ImageJ software, the L. monocytogenes mortality rate could reach about $97.25 \%$, which higher than other bacteriocins at the same concentration [22]. It suggested that plantaricin Q7 showed not only antibacterial activity but also a significant killing effect on L. monocytogenes. 
A

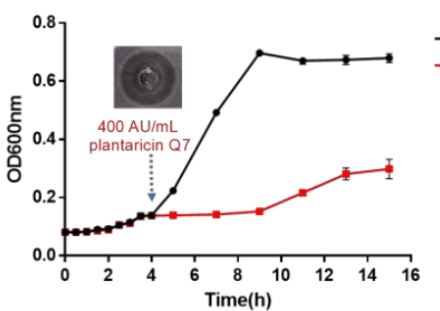

B

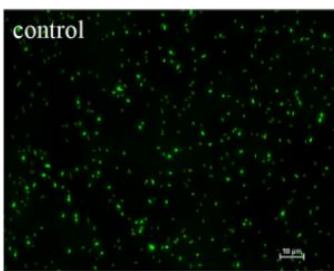

Figure 1. Antibacterial activity of plantaricin Q7 against L. monocytogenes. (A) Effect of plantaricin Q7 on the growth curve of L. monocytogenes. (B) Effect of plantaricin Q7 on the survival rate of $L$. monocytogenes. The data were shown as mean $\pm \mathrm{SD}(n=3)$.

\subsection{Effects of Plantaricin Q7 on Morphology and Internal Structure of L. monocytogenes}

TEM was employed to observe the surface morphological and intracellular structural changes of L. monocytogenes. As shown in Figure 2A,C, the untreated L. monocytogenes cells had a complete, clear and well-defined short rod shape, and the internal cytoplasm was uniformly distributed. After treatment with $400 \mathrm{AU} / \mathrm{mL}$ plantaricin Q7, it was observed that the surface of the cells was collapsed and the cell membrane was damaged. The boundary of the cell wall was blurred and the intracellular constituent leaked out (Figure 2B,D). The changes in cell morphology and internal structure indicated that the intact L. monocytogenes cell was damaged by plantaricin Q7. Therefore, plantaricin Q7 might kill L. monocytogenes by affecting cell morphology and internal structure, and the results were consistent with Yi et al. [31], who reported that lactocin XN8-A (LXA) could kill E. coli and S. aureus. After treatment of LXA, separation occured between the plasma membrane and the cell wall, and the cytoplasmic density decreased.
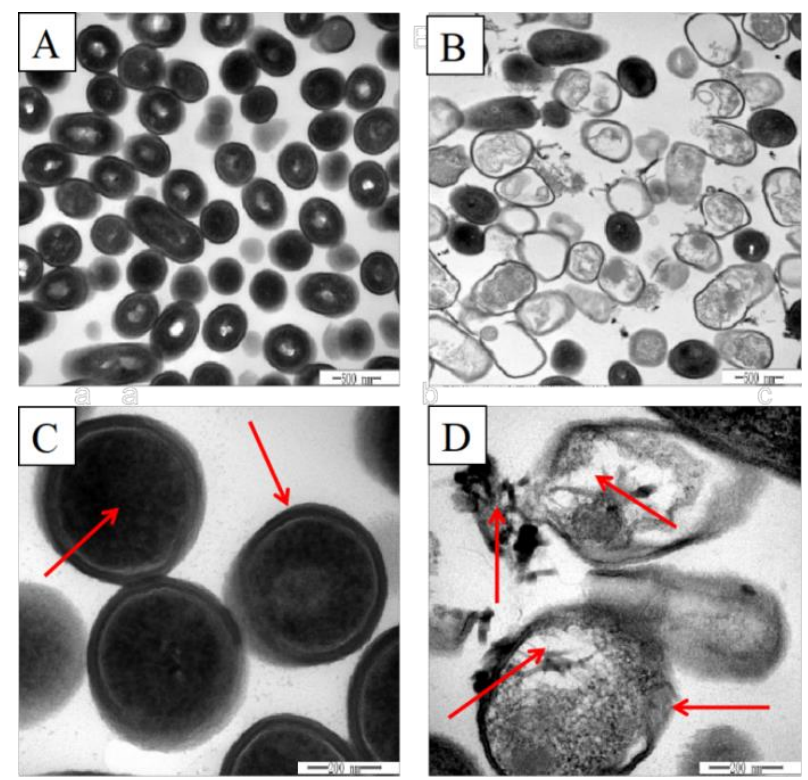

Figure 2. Effects of plantaricin Q7 on the morphology and internal structure of L. monocytogenes. (A,C) Control group, (B,D) treatment group, (A,B) 40,000× magnification, (C,D) 150,000× magnification. The red arrows in Figure 2C,D pointed to the cell wall and cell content of the bacteria in the control group and the treatment group respectively.

\subsection{Effects of Plantaricin Q7 on Intracellular Substances Leakage of L. monocytogenes}

Proteins were macromolecular substances involved in various physiological activities such as metabolism and electron transport [32]. Disrupting or blocking the synthesis of proteins was one of the modes of bacteriostasis substances [33]. It was found that the whole- 
cell protein bands of L. monocytogenes were complete and strong intensities in untreated samples, while the protein bands became lighter or even disappeared when the samples were exposed to $400 \mathrm{AU} / \mathrm{mL}$ plantaricin Q7 for $10 \mathrm{~h}$ (Figure 3A). The results indicated that plantaricin Q7 could inhibit the growth of L. monocytogenes by affecting the synthesis of L. monocytogenes cell proteins. Our results were consistent with the report of Kang et al. [23], who pointed out that ferulic acid could inactivate S. flexneri through affecting the expression of cell proteins.

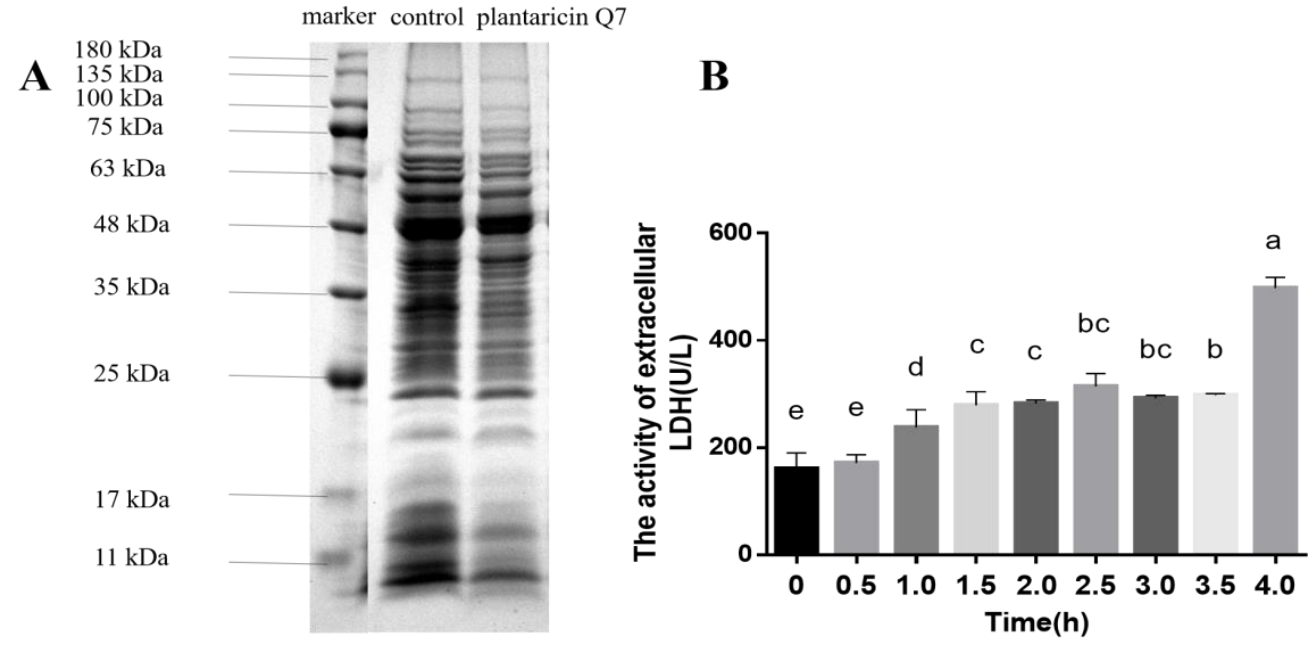

Figure 3. Effects of plantaricin Q7 on intracellular substances leakage of L. monocytogenes. (A) Effect of plantaricin Q7 on L. monocytogenes cell protein. (B) Effects of plantaricin Q7 on LDH activity. The data were shown as mean $\pm \mathrm{SD}(n=3)$. Different letters in the figure denoted significant statistical differences $(p<0.05)$.

$\mathrm{LDH}$ is a glycolytic enzyme that catalyzes the dehydrogenation of lactic acid into pyruvate [34]. Normally, only a small amount of LDH is present outside the cell [35]. The activity of LDH was evaluated and the results was shown in Figure 3B. The LDH activity of L. monocytogenes increased slowly from $0 \mathrm{~h}$ to $2.5 \mathrm{~h}$ when treated with $400 \mathrm{AU} / \mathrm{mL}$ plantaricin Q7, and decreased slightly between $2.5 \mathrm{~h}$ and $3.5 \mathrm{~h}$. After $4 \mathrm{~h}$ of intervention, the $\mathrm{LDH}$ activity increased rapidly from $156.74 \mathrm{U} / \mathrm{L}$ to $497.62 \mathrm{U} / \mathrm{L}$. It suggested that the cell membrane was damaged when treated with $400 \mathrm{AU} / \mathrm{mL}$ plantaricin Q7 for $4 \mathrm{~h}$. These findings indicated that the leakage of intracellular macromolecular leaded to the death of $L$. monocytogenes. Li et al. [36] found that the leakage of cell contents reflected the mode of action of antimicrobial peptides, which usually formed holes in the cell membrane.

\subsection{Effects of Plantaricin $Q 7$ on $\mathrm{K}^{+}$Concentration and Electrical Conductivity of L. monocytogenes}

Small electrolytes are more likely to leak preferentially than large molecules such as proteins and LDH. Bacterial cytoplasmic membrane provides a permeable surface for $\mathrm{Na}^{+}$, $\mathrm{K}^{+}$and $\mathrm{H}^{+}$ions, which plays an important role in promoting the functions of cell membrane and maintaining enzymatic activity and normal physiological metabolism $[37,38]$. The $\mathrm{K}^{+}$concentration and the electrical conductivity of L. monocytogenes were assayed. The results showed that the concentration of extracellular $\mathrm{K}^{+}$increased rapidly from $0.02 \mathrm{~g} / \mathrm{L}$ to $0.09 \mathrm{~g} / \mathrm{L}$ after treatment of $400 \mathrm{AU} / \mathrm{mL}$ plantaricin Q7 (Figure $4 \mathrm{~A}$ ). At the same time, the electrical conductivity of the treatment group increased from $14.21 \mathrm{mS} / \mathrm{cm}$ to $16.01 \mathrm{mS} / \mathrm{cm}$ (Figure 4B). The change of electrical conductivity induced by plantaricin Q7 might explain the cell death by increasing cell membrane permeability. Many antimicrobial substances inhibited or killed bacteria mediated by changing cell membrane permeability and integrity $[22,23,39]$. Taken together, plantaricin Q7 could affect L. monocytogenes growth by causing the irreversible damage of the morphology and the integrity of cell membrane. 
A

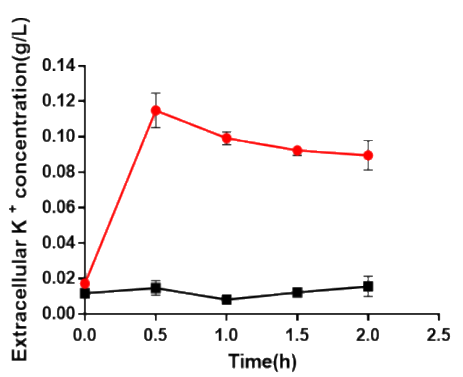

B

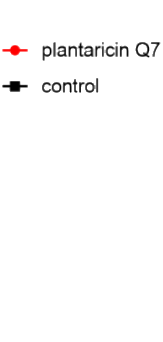

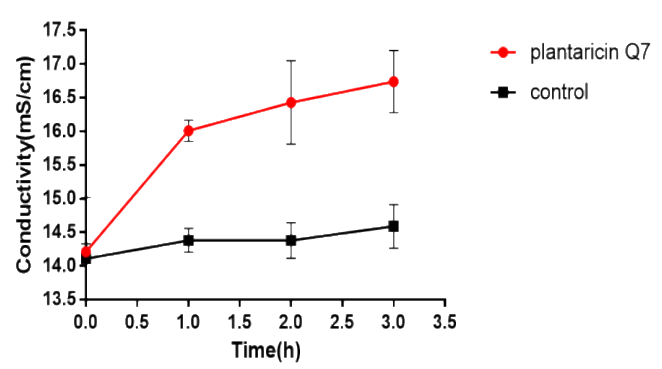

Figure 4. Effects of plantaricin $\mathrm{Q} 7$ on $\mathrm{K}^{+}$concentration and electrical conductivity of L. monocytogenes. (A) $\mathrm{K}^{+}$concentration. (B) Electrical conductivity. The data were shown as mean $\pm \mathrm{SD}(n=3)$.

\subsection{Effects of Plantaricin Q7 on the Motility and Attachment of L. monocytogenes}

The important period of biofilm formation is the adhesion process of planktonic cells on the surface of objects. Cell motility was closely related to the ability of cells adhesion [40]. The soft agar tube test showed that the $400 \mathrm{AU} / \mathrm{mL}$ plantaricin Q7 treatment group significantly reduced flagellum motility in comparison with the control group (Figure 5A). In addition, it was observed that the spots formed by the plantaricin Q7 treatment group were smaller than those of the control group (Figure 5B), which suggested that the motility of L. monocytogenes treated with plantaricin Q7 was remarkably reduced. Therefore, plantaricin Q7 might reduce the harmfulness of L. monocytogenes by weakening its motility and reducing its spread range.

A

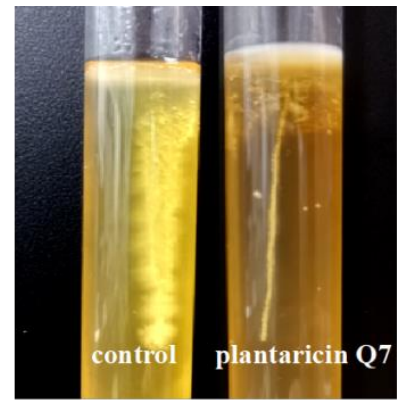

B

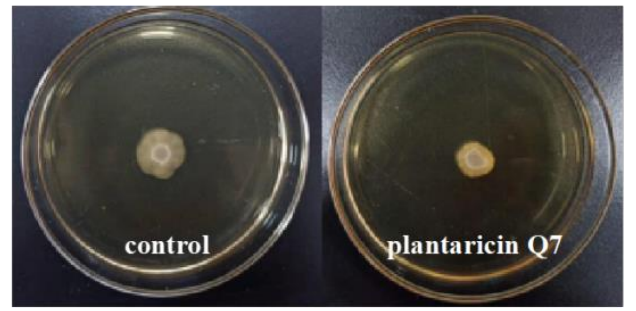

C

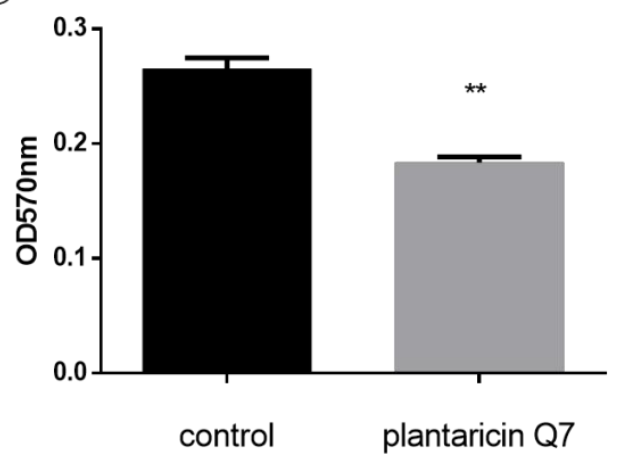

Figure 5. Effects of plantaricin $\mathrm{Q7}$ on the motility and attachment of L. monocytogenes. (A) L. monocytogenes flagellum puncture test. (B) Effect of plantaricin Q7 on crawling movement ability of $L$. monocytogenes. (C) Effect of plantaricin Q7 on the ability of L. monocytogenes to attach fibrinogen. The data were shown as mean $\pm \operatorname{SD}(n=3) .{ }^{* *} p<0.01$.

The attachment ability was an important factor in the evaluation of biofilm formation [28]. The influence of $400 \mathrm{AU} / \mathrm{mL}$ plantaricin $\mathrm{Q} 7$ on L. monocytogenes adhesion was examined. The results in Figure $5 \mathrm{C}$ indicated that plantaricin $\mathrm{Q7}$ reduced the relative 
adhesion rate of L. monocytogenes to fibrinogen significantly. Compared with the control group, the relative adhesion rate of L. monocytogenes in the sample group decreased by about $30 \%$, which was one of the important factors affecting the formation of biofilm. Vazquez-Armenta et al. [41] reported that quercetin inhibited L. monocytogenes biofilm formation by reducing the initial attachment and the number of extracellular proteins, which was partially consistent with the results of our study.

\subsection{Inhibitory Effect of Plantaricin Q7 on the Formation of L. monocytogenes Biofilm}

The time of L. monocytogenes biofilm formation was determined (Figure 6). It could be found that the biofilm began to form at $12 \mathrm{~h}$. When cultured for $24 \mathrm{~h}$, the biofilm formed was more dense and the adhesion was stronger, and the biofilm was in the mature stage. After being cultured for $48 \mathrm{~h}$, the biofilm structure was decreased, which indicated that the biofilm was in the diffusion stage. Therefore, we selected $24 \mathrm{~h}$ as the most appropriate time for the formation of L. monocytogenes biofilm, and the inhibitory and reducing effects of plantaricin Q7 on L. monocytogenes biofilm were studied respectively.

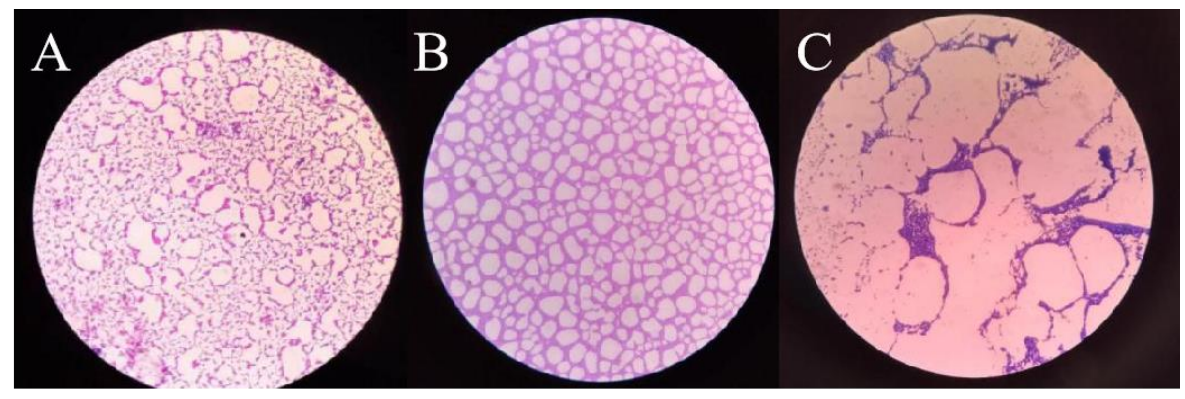

Figure 6. Crystal violet stained biofilm. (A-C) represented the biofilms cultured for $12 \mathrm{~h}, 24 \mathrm{~h}$ and $48 \mathrm{~h}$ respectively, observed by $40 \times$ magnification microscope.

The inhibitory capacities of plantaricin Q7 on L. monocytogenes biofilm formation was characterized by employing optical microscope and SEM. As presented in Figure 7, it was showed that many tightly adhered cells wrapped on glass coverslips, and the morphology of the cells was intact in the control group. In contrast, the biofilm exposed to $400 \mathrm{AU} / \mathrm{mL}$ plantaricin Q7 were almost invisible. In addition, though there was a sharp decline in quantity of L. monocytogenes cells in biofilm, no significant change of cell morphology was observed. The morphology of L. monocytogenes cell was inconsistent before and after the biofilm formation when treated by plantaricin Q7. These findings indicated that plantaricin Q7 exhibited obvious inhibitory effect on L. monocytogenes biofilm formation. It was agreeable with the findings of Borges et al. [42], who observed that ferulic acid and gallic acid hindered the adhesion and biofilm formation of E. coli, L. monocytogenes, P. aeruginosa, and S. aureus.

\subsection{Effect of Plantaricin Q7 on L. monocytogenes Biofilm Reduction}

The reduction effect of plantaricin Q7 on L. monocytogenes biofilm was investigated. As shown in Figure 8, the biofilm structure was dense and strongly adherent to the glass coverslip in control groups which treated with PBS for $24 \mathrm{~h}$, while the dense spider web structure was destroyed after treated with $400 \mathrm{AU} / \mathrm{mL}$ plantaricin Q7 for $24 \mathrm{~h}$, and the biofilm was completely disintegrated. Moreover, the results (Figure 8D,H) showed that L. monocytogenes in the control group presented a complete, clear profile. Conversely, few bacteria with intact cell membrane were detected after treated with plantaricin Q7. Interesting, the results showed that there might be different mechanisms for plantaricin Q7 to inhibit biofilm formation and reduce L. monocytogenes biofilm. Therefore, plantaricin Q7 can be further considered as a potential preservatives with antibiofilm activity, particularly against food-borne L. monocytogenes and its biofilm. Several studies showed that some bacteriostatic substances significantly reduced biofilm of pathogenic bacteria. Mishra et al. [43] 
designed antimicrobial peptides and found that the peptides inhibited the formation of $S$. aureus biofilm as well as destroy the formed S. aureus biofilm, which was similar with the phenomenon in our study. García et al. found the bacteriocin produced by L. lactis UQ2 reduced L. monocytogenes adhersion to stainless steel chips [44]. The mechanism of inhibition and reduction of biofilm needs to be further studied.

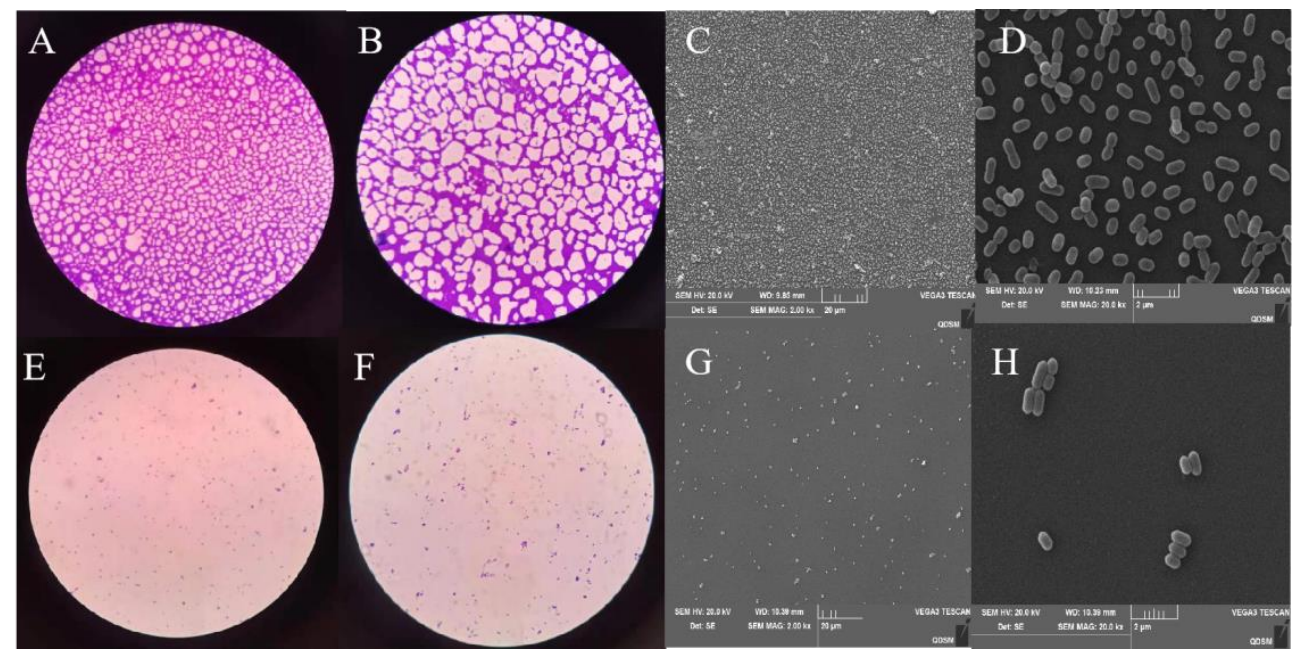

Figure 7. Inhibitory effect of plantaricin Q7 on the formation of L. monocytogenes biofilm. Optical microscope (A,B,E,F) and scanning electron microscope $(\mathbf{C}, \mathbf{D}, \mathbf{G}, \mathbf{H})$ images. Control group (A-D), treatment group (E-H). 40× magnification (A,E), $100 \times$ magnification oil lens $(\mathbf{B}, \mathbf{F}), 2000 \times$ magnification $(\mathbf{C}, \mathbf{G}), 20,000 \times$ magnification $(\mathbf{D}, \mathbf{H})$.

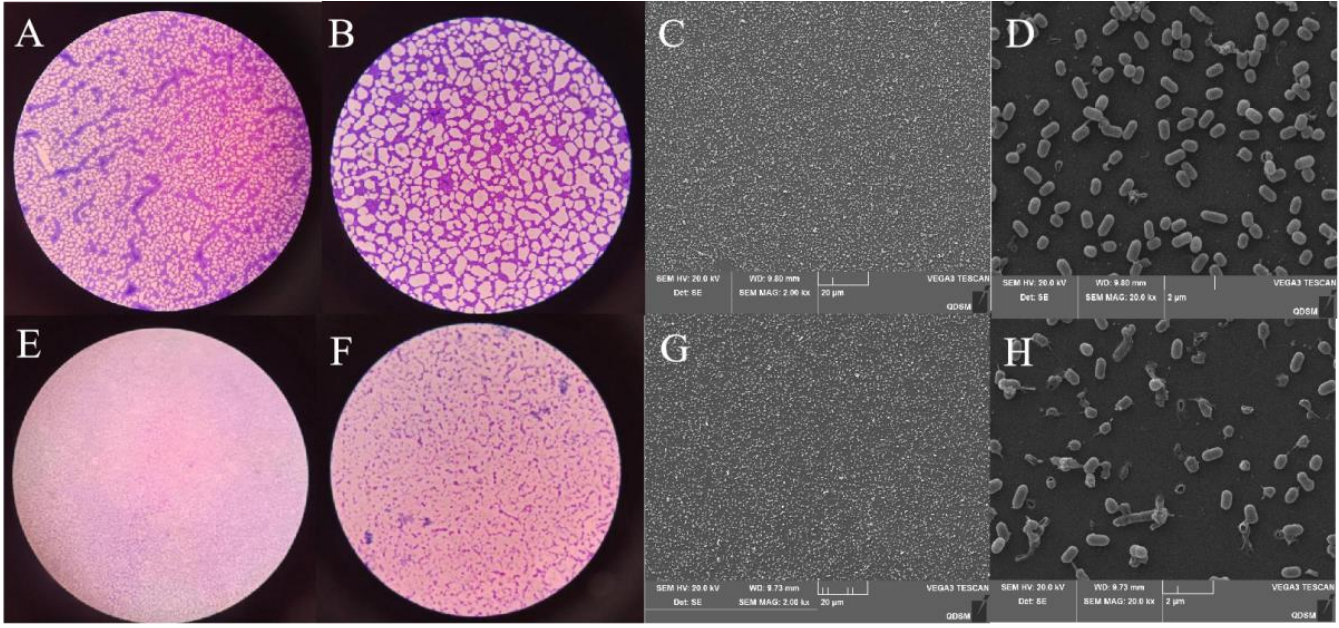

Figure 8. Effect of plantaricin Q7 on L. monocytogenes biofilm reduction. Optical microscope (A,B,E,F) and scanning electron microscope $(\mathbf{C}, \mathbf{D}, \mathbf{G}, \mathbf{H})$ images. Control group (A-D), treatment group (E-H). $40 \times$ magnification $(\mathbf{A}, \mathbf{E}), 100 \times$ magnification oil lens $(\mathbf{B}, \mathbf{F}), 2000 \times$ magnification $(\mathbf{C}, \mathbf{G}), 20,000 \times$ magnification $(\mathbf{D}, \mathbf{H})$.

\section{Conclusions}

In summary, the inhibitory effect of plantaricin Q7 on L. monocytogenes and its biofilm were investigated from the aspects of cell survival rate, cell membrane integrity and cell membrane permeability. It was found that plantaricin Q7 could not only inhibit the growth of L. monocytogenes, but also inhibit the biofilm formation of $L$. monocytogenes and reduce the matured L. monocytogenes biofilm, which provided a basis information for the development of plantaricin Q7 as food preservatives. 


\begin{abstract}
Author Contributions: Conceptualization, Y.L. (Yinxue Liu) and H.Y.; methodology, Y.L. (Yinxue Liu) and Y.B.; software, Y.L. (Yinxue Liu) and J.L.; formal analysis, Y.L. (Yinxue Liu), Y.B., J.L.; investigation, Y.L. (Yisuo Liu), A.L., P.G., T.L.; data curation, Y.L. (Yinxue Liu); Supervision, P.G., T.L.; writing—original draft preparation, Y.L. (Yinxue Liu); writing—review and editing, H.Y., S.W. and L.Z.; project administration, H.Y. and S.W.; funding acquisition, H.Y. All authors have read and agreed to the published version of the manuscript.
\end{abstract}

Funding: This research was funded by National Natural Science Foundation of China (No. 32172180, 31801516) and Key Program of Natural Science Foundation of Shandong Province in China (No. ZR2020KC009).

Institutional Review Board Statement: Not applicable.

Informed Consent Statement: Not applicable.

Data Availability Statement: The data presented in this study are available on request from the corresponding author.

Conflicts of Interest: The authors declare no competing interests. All authors consent to publication of this manuscript.

\title{
References
}

1. Farber, J.M.; Zwietering, M.; Wiedmann, M.; Schaffner, D.; Hedberg, C.W.; Harrison, M.A.; Hartnett, E.; Chapman, B.; Donnelly, C.W.; Goodburn, K.E.; et al. Alternative approaches to the risk management of Listeria monocytogenes in low risk foods. Food Control 2020, 123, 107601. [CrossRef]

2. Labite, H.; Lunani, I.; Van Der Steen, P.; Vairavamoorthy, K.; Drechsel, P.; Lens, P. Quantitative Microbial Risk Analysis to evaluate health effects of interventions in the urban water system of Accra, Ghana. J. Water Health 2010, 8, 417-430. [CrossRef] [PubMed]

3. Boelaert, F.; Amore, G.; Van der Stede, Y.; Hugas, M. EU-wide monitoring of biological hazards along the food chain: Achievements, challenges and EFSA vision for the future. Curr. Opin. Food Sci. 2016, 12, 52-62. [CrossRef]

4. $\quad$ Chen, S.-Y.; Lee, J.-J.; Chien, C.-C.; Tsai, W.-C.; Lu, C.-H.; Chang, W.-N.; Lien, C.-Y. High incidence of severe neurological manifestations and high mortality rate for adult Listeria monocytogenes meningitis in Taiwan. J. Clin. Neurosci. 2019, 71, 177-185. [CrossRef] [PubMed]

5. Liu, Y.; Sun, W.; Sun, T.; Gorris, L.G.; Wang, X.; Liu, B.; Dong, Q. The prevalence of Listeria monocytogenes in meat products in China: A systematic literature review and novel meta-analysis approach. Int. J. Food Microbiol. 2019, 312, 108358. [CrossRef] [PubMed]

6. Lebreton, A.; Stavru, F.; Cossart, P. Organelle targeting during bacterial infection: Insights from Listeria. Trends Cell Biol. 2015, 25, 330-338. [CrossRef]

7. Mammina, C.; Aleo, A.; Romani, C.; Pellissier, N.; Nicoletti, P.; Pecile, P.; Nastasi, A.; Pontello, M.M. Characterization of Listeria monocytogenes Isolates from Human Listeriosis Cases in Italy. J. Clin. Microbiol. 2009, 47, 2925-2930. [CrossRef] [PubMed]

8. Forauer, E.; Wu, S.T.; Etter, A.J. Listeria monocytogenes in the retail deli environment: A review. Food Control 2020, 119, 107443. [CrossRef]

9. Di Bonaventura, G.; Piccolomini, R.; Paludi, D.; D'Orio, V.; Vergara, A.; Conter, M.; Ianieri, A. Influence of temperature on biofilm formation by Listeria monocytogenes on various food-contact surfaces: Relationship with motility and cell surface hydrophobicity. J. Appl. Microbiol. 2008, 104, 1552-1561. [CrossRef]

10. Abdallah, M.; Benoliel, C.; Drider, D.; Dhulster, P.; Chihib, N.-E. Biofilm formation and persistence on abiotic surfaces in the context of food and medical environments. Arch. Microbiol. 2014, 196, 453-472. [CrossRef]

11. Beleneva, I.A. Incidence and characteristics of Staphylococcus aureus and Listeria monocytogenes from the Japan and South China seas. Mar. Pollut. Bull. 2011, 62, 382-387. [CrossRef] [PubMed]

12. Kang, M.-Y.; Jeong, H.-W.; Kim, J.; Lee, J.-W.; Jang, J. Removal of biofilms using carbon dioxide aerosols. J. Aerosol Sci. 2010, 41, 1044-1051. [CrossRef]

13. Shea, E.F.O.; Cotter, P.D.; Ross, R.P.; Hill, C. Strategies to improve the bacteriocin protection provided by lactic acid bacteria. Curr Opin. Biotechnol. 2013, 24, 130-134. [CrossRef] [PubMed]

14. Cotter, P.D.; Ross, R.; Hill, C. Bacteriocins-A viable alternative to antibiotics? Nat. Rev. Genet. 2012, 11, 95-105. [CrossRef]

15. Yang, S.-Y.; Chae, S.A.; Bang, W.Y.; Lee, M.; Ban, O.-H.; Kim, S.-J.; Jung, Y.H.; Yang, J. Anti-inflammatory potential of Lactiplantibacillus plantarum IDCC 3501 and its safety evaluation. Braz. J. Microbiol. 2021, 52, 2299-2306. [CrossRef]

16. Zacharof, M.-P.; Coss, G.M.; Mandale, S.; Lovitt, R. Separation of lactobacilli bacteriocins from fermented broths using membranes. Process Biochem. 2013, 48, 1252-1261. [CrossRef]

17. Liu, H.; Zhang, L.; Yi, H.; Han, X.; Chi, C. Identification and characterization of plantaricin Q7, a novel plantaricin produced by Lactobacillus plantarum Q7. LWT-Food Sci. Technol. 2016, 71, 386-390. [CrossRef] 
18. Bu, Y.; Liu, Y.; Li, J.; Liu, T.; Gong, P.; Zhang, L.; Wang, Y.; Yi, H. Analyses of plantaricin Q7 synthesis by Lactobacillus plantarum Q7 based on comparative transcriptomics. Food Control 2021, 124, 107909. [CrossRef]

19. An, Y.; Wang, Y.; Liang, X.; Yi, H.; Zuo, Z.; Xu, X.; Zhang, D.; Yu, C.; Han, X. Purification and partial characterization of M1-UVs300, a novel bacteriocin produced by Lactobacillus plantarum isolated from fermented sausage. Food Control 2017, 81, 211-217. [CrossRef]

20. Engelhardt, T.; Albano, H.; Kiskó, G.; Mohácsi-Farkas, C.; Teixeira, P. Antilisterial activity of bacteriocinogenic Pediococcus acidilactici HA6111-2 and Lactobacillus plantarum ESB 202 grown under $\mathrm{pH}$ and osmotic stress conditions. Food Microbiol. 2015, 48, 109-115. [CrossRef]

21. Wang, X.; Teng, D.; Mao, R.; Yang, N.; Hao, Y.; Wang, J. Combined Systems Approaches Reveal a Multistage Mode of Action of a Marine Antimicrobial Peptide against Pathogenic Escherichia coli and Its Protective Effect against Bacterial Peritonitis and Endotoxemia. Antimicrob. Agents Chemother. 2017, 61, e01056-16. [CrossRef] [PubMed]

22. Li, H.-W.; Xiang, Y.-Z.; Zhang, M.; Jiang, Y.-H.; Zhang, Y.; Liu, Y.-Y.; Lin, L.-B.; Zhang, Q.-L. A novel bacteriocin from Lactobacillus salivarius against Staphylococcus aureus: Isolation, purification, identification, antibacterial and antibiofilm activity. LWT-Food Sci. Technol. 2020, 140, 110826. [CrossRef]

23. Kang, J.; Liu, L.; Liu, Y.; Wang, X. Ferulic Acid Inactivates Shigella flexneri through Cell Membrane Destructieon, Biofilm Retardation, and Altered Gene Expression. J. Agric. Food Chem. 2020, 68, 7121-7131. [CrossRef] [PubMed]

24. Wang, C.; Chang, T.; Yang, H.; Cui, M. Antibacterial mechanism of lactic acid on physiological and morphological properties of Salmonella Enteritidis, Escherichia coli and Listeria monocytogenes. Food Control 2015, 47, 231-236. [CrossRef]

25. Liu, Y.; Shi, C.; Zhang, G.; Zhan, H.; Liu, B.; Li, C.; Wang, L.; Wang, H.; Wang, J. Antimicrobial mechanism of 4hydroxyphenylacetic acid on Listeria monocytogenes membrane and virulence. Biochem. Biophys. Res. Commun. 2021, 572, 145-150. [CrossRef]

26. Todhanakasem, T.; Young, G.M. Loss of Flagellum-Based Motility by Listeria monocytogenes Results in Formation of Hyperbiofilms. J. Bacteriol. 2008, 190, 6030-6034. [CrossRef]

27. Li, J.; Qiao, M.; Zhang, X.; Li, J.; Meng, Q.; Qiao, J.; Li, Y.; Wang, X.; Zhang, G.; Zhang, K.; et al. Effects of Lmo2672 Deficiency on Environmental Adaptability, Biofilm Formation, and Motility of Listeria monocytogenes. Jundishapur J. Microbiol. 2020, 13, 1-8. [CrossRef]

28. Ming, D.; Wang, D.; Cao, F.; Xiang, H.; Mu, D.; Cao, J.; Li, B.; Zhong, L.; Dong, X.; Zhong, X.; et al. Kaempferol Inhibits the Primary Attachment Phase of Biofilm Formation in Staphylococcus aureus. Front. Microbiol. 2017, 8, 2263. [CrossRef]

29. O'Toole, G.A.; Kolter, R. Initiation of biofilm formation in Pseudomonas fluorescensWCS365 proceeds via multiple, convergent signalling pathways: A genetic analysis. Mol. Microbiol. 1998, 28, 449-461. [CrossRef]

30. Liu, Y.; Xia, X.; Xu, L.; Wang, Y. Design of hybrid $\beta$-hairpin peptides with enhanced cell specificity and potent anti-inflammatory activity. Biomaterials 2013, 34, 237-250. [CrossRef]

31. Yi, L.; Dang, J.; Zhang, L.; Wu, Y.; Liu, B.; Lü, X. Purification, characterization and bactericidal mechanism of a broad spectrum bacteriocin with antimicrobial activity against multidrug-resistant strains produced by Lactobacillus coryniformis XN8. Food Control 2016, 67, 53-62. [CrossRef]

32. Jin, F. Structural insights into the mechanism of a novel protein targeting pathway in Gram-negative bacteria. FEBS Open Bio 2020, 10, 561-579. [CrossRef] [PubMed]

33. Hernandez-Guerrero, R.; Galán-Vásquez, E.; Pérez-Rueda, E. The protein architecture in Bacteria and Archaea identifies a set of promiscuous and ancient domains. PLoS ONE 2019, 14, e0226604. [CrossRef] [PubMed]

34. Kolappan, S.; Shen, D.L.; Mosi, R.; Sun, J.; McEachern, E.; Vocadlo, D.; Craig, L. Structures of lactate dehydrogenase A (LDHA) in apo, ternary and inhibitor-bound forms. Acta Crystallogr. Sect. D Biol. Crystallogr. 2015, 71, 185-195. [CrossRef] [PubMed]

35. Sato, J.; Wakayama, M.; Takagi, K. Lactate Dehydrogenase Involved in Lactate Metabolism of Acetobacter Pasteurianus. Procedia Environ. Sci. 2015, 28, 67-71. [CrossRef]

36. Li, S.; Wang, Y.; Xue, Z.; Jia, Y.; Li, R.; He, C.; Chen, H. The structure-mechanism relationship and mode of actions of antimicrobial peptides: A review. Trends Food Sci. Technol. 2021, 109, 103-115. [CrossRef]

37. Diao, W.-R.; Zhang, L.-L.; Feng, S.-S.; Xu, J.-G. Chemical Composition, Antibacterial Activity, and Mechanism of Action of the Essential Oil from Amomum kravanh. J. Food Prot. 2014, 77, 1740-1746. [CrossRef]

38. Suzuki, M.; Yamamoto, T.; Kawai, Y.; Inoue, N.; Yamazaki, K. Mode of action of piscicocin CS526 produced by Carnobacterium piscicola CS526. Appl. Microbiol. 2005, 98, 1146-1151. [CrossRef]

39. Rurián-Henares, J.A.; Morales, F.J. Antimicrobial Activity of Melanoidins against Escherichia coli Is Mediated by a MembraneDamage Mechanism. J. Agric. Food Chem. 2008, 56, 2357-2362. [CrossRef]

40. Lemon, K.P.; Higgins, D.E.; Kolter, R. Flagellar Motility Is Critical for Listeria monocytogenes Biofilm Formation. J. Bacteriol. 2007, 189, 4418-4424. [CrossRef]

41. Vazquez-Armenta, F.; Bernal-Mercado, A.; Rodriguez, M.R.T.; Gonzalez-Aguilar, G.; Lopez-Zavala, A.; Martínez-Téllez, M.; Oñate, M.H.; Ayala-Zavala, J. Quercetin reduces adhesion and inhibits biofilm development by Listeria monocytogenes by reducing the amount of extracellular proteins. Food Control 2018, 90, 266-273. [CrossRef]

42. Borges, A.; Maria, J.; Simoes, M. The activity of ferulic and gallic acids in biofilm prevention and control of pathogenic bacteria. Biofouling 2012, 28, 755-767. [CrossRef] [PubMed] 
43. Mishra, B.; Golla, R.M.; Lau, K.; Lushnikova, T.; Wang, G. Anti-Staphylococcal Biofilm Effects of Human Cathelicidin Peptides. ACS Med. Chem. Lett. 2015, 7, 117-121. [CrossRef] [PubMed]

44. García-Almendárez, B.E.; Cann, I.K.; Martin, S.E.; Guerrero-Legarreta, I.; Regalado, C. Effect of Lactococcus lactis UQ2 and its bacteriocin on Listeria monocytogenes biofilms. Food Control 2008, 19, 670-680. [CrossRef] 